\title{
Predicting outcome from dengue
}

\author{
Sophie Yacoub ${ }^{1,2^{*}}$ and Bridget Wills ${ }^{1,3}$
}

\begin{abstract}
Dengue is emerging as one of the most abundant vector-borne disease globally. Although the majority of infections are asymptomatic or result in only a brief systemic viral illness, a small proportion of patients develop potentially fatal complications. These severe manifestations, including a unique plasma leakage syndrome, a coagulopathy sometimes accompanied by bleeding, and organ impairment, occur relatively late in the disease course, presenting a window of opportunity to identify the group of patients likely to progress to these complications. However, as yet, differentiating this group from the thousands of milder cases seen each day during outbreaks remains challenging, and simple and inexpensive strategies are urgently needed in order to improve case management and to facilitate appropriate use of limited resources. This review will cover the current understanding of the risk factors associated with poor outcome in dengue. We focus particularly on the clinical features of the disease and on conventional investigations that are usually accessible in mid-level healthcare facilities in endemic areas, and then discuss a variety of viral, immunological and vascular biomarkers that have the potential to improve risk prediction. We conclude with a description of several novel methods of assessing vascular function and intravascular volume status non-invasively.
\end{abstract}

Keywords: Dengue, Severity, Outcome, Risk factors, Biomarkers, Vascular

\section{Introduction}

Dengue is the most important arboviral infection affecting humans, and presents a major challenge for public health services worldwide. Infection can be caused by any of four dengue virus serotypes (DENV1 to 4), transmitted by Aedes mosquitoes. Over half the world's population is thought to live in areas at risk for transmission, and recent estimates suggest that around 400 million infections occur annually, of which 100 million are clinically apparent [1]. The clinical phenotype varies from a mild self-limiting febrile illness through to severe and occasionally life-threatening disease. Symptomatic disease typically follows three phases: an initial febrile phase lasting 3 to 7 days; a critical phase around defervescence, during which complications appear in a small proportion of patients; and a spontaneous recovery phase. Complications primarily affect the vascular system, and include an unusual plasma leakage syndrome that may result in hypovolaemic shock - the potentially fatal dengue

\footnotetext{
* Correspondence: syacoub@imperial.ac.uk

'Oxford University Clinical Research Unit, Wellcome Trust Major Overseas Programme, Hospital for Tropical Diseases, 764 Vo Van Kiet Street, Ho Chi Minh City, Vietnam

${ }^{2}$ Department of Medicine, Imperial College, Hammersmith Campus, London, UK

Full list of author information is available at the end of the article
}

shock syndrome (DSS); a coagulopathy sometimes accompanied by bleeding; and organ impairment [2]. Because these severe manifestations occur relatively late in the disease course, often when the infecting virus is no longer detectable in plasma, immune-mediated mechanisms are postulated to play a significant role in pathogenesis [3]. Currently no vaccine is available, and neither antiviral drugs nor immunomodulatory agents have been shown to be effective in reducing morbidity or improving disease outcome [4-7]. However, with good supportive care (primarily judicious use of parenteral fluid therapy to offset plasma volume losses due to leakage), mortality rates of less than $1 \%$ are possible even among DSS cases $[8,9]$.

Although the vast majority of symptomatic infections do not progress to severe disease, areas of high dengue transmission can have seasonal epidemics, which can quickly overwhelm health service capacity. Thus, the ability to identify patients at high risk of progression, who are likely to benefit from close observation and early intervention with supportive therapy, has become the focus of intense research efforts in recent years. In 2009, the World Health Organization (WHO) revised the classification system for dengue, defining two major entities - dengue and severe dengue - to replace the more complicated dengue fever/dengue haemorrhagic 
fever (DF/DHF) system used previously [10]. The new classification also encompasses a set of 'warning signs' intended to help clinicians identify patients likely to develop complications during the critical phase of the illness (Figure 1). These signs and symptoms were derived in part from a dataset describing almost 2,000 patients with dengue across Asia and Latin America, but owing to the small number of patients progressing to severe disease during the study, further work is needed to validate the findings [11].

This review will focus on the current knowledge of factors associated with disease progression, either considered in terms of DHF/DSS or dengue with warning signs/severe dengue. We concentrate first on readily accessible parameters, that is, the clinical features of the disease and the conventional investigations available in most mid-level healthcare facilities, before discussing a variety of potential viral, immunological and vascular biomarkers that have been proposed. Finally we conclude by describing a number of novel non-invasive methods of assessing vascular function or intravascular volume status, and consider their potential relevance for dengue.

\section{Clinical features and standard laboratory or radiological investigations}

Epidemiological studies have identified a number of risk factors for more severe dengue disease, including secondary infection [13], the two extremes of age [14,15], pregnancy [16], under-nutrition and over-nutrition [17], and the presence of comorbidities such as diabetes and hypertension in adults [18]. Male patients are often overrepresented in dengue epidemics, but female sex has been associated with more severe disease [19-21]. Several groups have attempted to identify the clinical symptoms and signs occurring during the acute illness that are associated with outcome. In a prospective study of 700 Vietnamese children with confirmed dengue, gastrointestinal symptoms and hepatomegaly were more prominent among those classified as having DHF, and a peak haematocrit above $50 \%$ was associated with DSS [22]. Clinical bleeding manifestations are highly variable, although skin petechiae are commonly observed across the severity spectrum, and the tourniquet test, one of the original diagnostic criteria for DHF, has been shown to differentiate poorly between DF and DHF [23,24]. In Singapore, where dengue is predominantly an adult disease, a decision tree involving clinical bleeding, high serum urea, low serum protein and low lymphocyte proportion was developed to predict likely progression to DHF among hospitalised patients; sensitivity and negative predictive value were high, but specificity was poor [25]. The decision tree was subsequently validated in another Singaporean cohort, and has been suggested as a tool to guide triage of patients who require hospitalisation versus outpatient treatment [26].

A number of haematological parameters have been considered as potential predictors, most commonly the platelet count [27]. Platelet counts tend to fall over the illness course, reaching a nadir shortly after defervescence, before demonstrating a rapid recovery response [28]. Lower counts $\left(<50 \times 10^{9} /\right.$; normal range 150 to $400 \times 10^{9} / \mathrm{l}$ ) are seen more frequently in severe disease [29], and are considered a risk factor for bleeding [30].

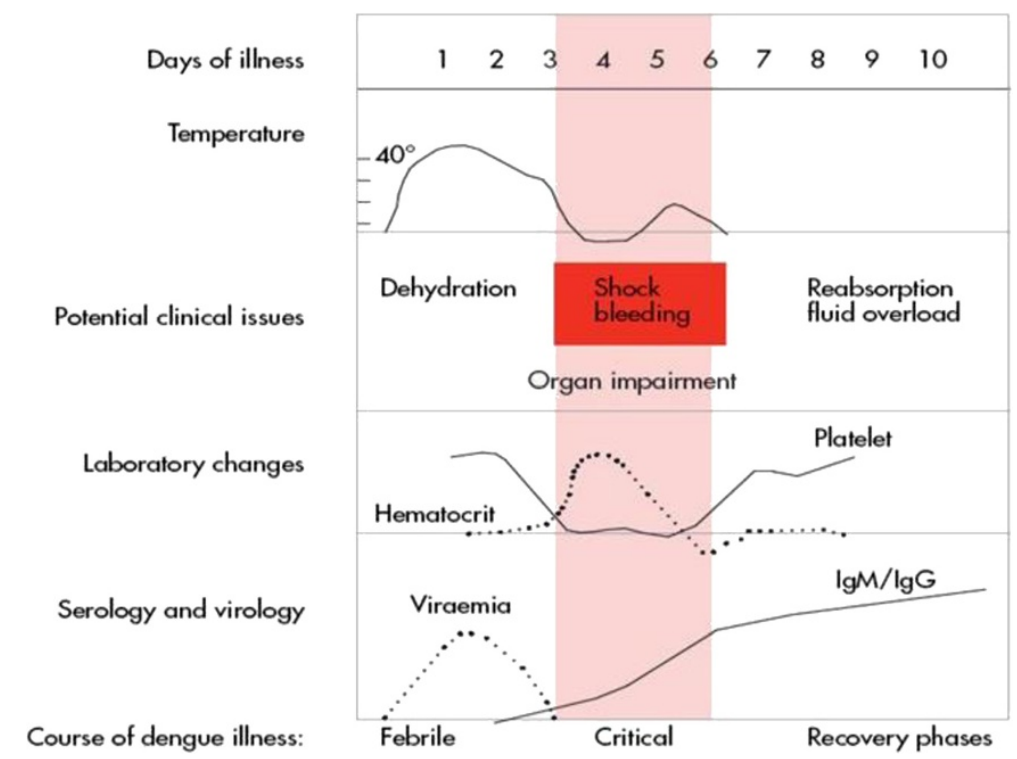

Figure 1 Dengue disease phases and potential complications. Reproduced, with permission of the publisher, from the WHO publication [12] (Figure 2.1; p. 25). 
However, the correlation between thrombocytopenia and haemorrhage is weak, with lower platelet counts correlating more closely with the severity of vascular leakage in one study [31].

Although a rapid decrease in platelet count concurrent with an increase in haematocrit is presented as one of the warning signs for likely progression to shock in the 2009 WHO dengue classification [32], specific values have not been defined as yet. Given the wide range of normal platelet values and the fact that the nadir occurs relatively late in the disease course, efforts have been made to develop prognostic algorithms that combine the platelet count with other haematological indices during the febrile phase. Using classification and regression tree analysis, algorithms based on platelet count, total white cell count, monocyte percentage and haematocrit level, obtained within 72 hours of fever onset, identified Thai children who went on to develop DSS with good sensitivity (97\%) but limited specificity (48\%) [33]. The rate of change in serial haematological markers, particularly the platelet count, may also carry important prognostic information, and efforts are in progress to develop models that incorporate longitudinal data from repeated sampling to see if this improves the accuracy of risk prediction.

Currently, clinical identification of vascular leakage is difficult until or unless DSS develops. The most common method of monitoring leakage relies on identification of relative haemoconcentration, determined by tracking changes in serial haematocrit measurements, with a rise of more than $20 \%$ from baseline considered evidence of significant leakage. However, this method can be rather insensitive, particularly if the patient is receiving parenteral fluid therapy, and it is also limited by the fact that an individual's baseline value is rarely known. Thus, although assessment of haemoconcentration can be helpful for case management, it is often only possible to appreciate the true severity of haemoconcentration once the acute illness has resolved and the haematocrit has returned to normal for that individual. Although comparison with age- and sex-matched population haematocrit values is recommended, such values are rarely available in dengue endemic areas [11].

Hepatic involvement is common in dengue, and liver enzymes are frequently elevated in infections of all severity grades. More marked derangements are usually associated with more severe disease profiles [34,35], but discrimination between severe and non-severe dengue has proved to be poor [36]. In addition, liver enzyme levels tend to peak late in the disease course, typically during the second week, limiting their usefulness as prognostic markers [35]. Hypoproteinaemia is well recognized during the critical phase, and correlates with the severity of leakage $[37,38]$; however, like haemoconcentration, hypoproteinaemia is difficult to identify without serial measurements or a known baseline value for an individual. Proteinuria also occurs, and marked increases in fractional clearances of several endogenous proteins have been documented among children with DSS [37]. The urine protein/creatinine ratio (UPCR) has been suggested as a possible predictor of outcome, with higher peak UPCRs observed in adult DHF cases compared to DF cases [38]. However, a study describing the magnitude and kinetics of urinary albumin excretion in a large paediatric population found that although albumin excretion was increased in the confirmed dengue patients, with a significant time-trend showing peak values during the critical phase, discrimination between patients of different severity was poor, and albuminuria was not useful in predicting the development of complications [39].

Studies using ultrasound have demonstrated that pleural effusions, ascites and gall bladder wall oedema are common during the critical phase, and correlate with disease severity [40-42]. In addition, serial ultrasound studies indicate that subclinical plasma leakage can be detected as early as days 2 to 3 of fever [43], and is better at predicting likely disease progression than other markers of plasma leakage such as haematocrit and albumin measurements [44]. Gallbladder wall oedema appears to precede the development of ascites and effusions, and may therefore be a helpful early predictor of outcome. Thus ultrasonography can be a useful monitoring tool, and where available, should be considered in the overall assessment during the febrile phase. However, there are certain limitations,particularly the lack of defined normal ranges for the parameters of interest, the variability in measurements obtained by different operators, and the lack of specificity of the findings. For example, gallbladder wall thickness may be increased in other infections and also in the postprandial state [45]. Finally, as yet, the availability of portable ultrasonography and the technical expertise necessary to interpret the images obtained remains relatively restricted in the resource-limited areas where dengue is endemic.

\section{Potential prognostic biomarkers}

In the face of the rapidly expanding global pandemic, many research groups are attempting to assess a variety of potential biomarkers for associations with dengue disease progression, and only a selected overview is possible here. Only human studies will be reviewed, as the true relevance of even the most sophisticated model systems to human dengue disease remains uncertain.

\section{Viral and immunological markers}

The observations that a) severe disease is more common in secondary infections with a different dengue virus (DENV) serotype and b) severe clinical manifestations typically occur when the viral load is in steep decline $[46,47]$, support the idea that the pathogenesis 
of severe dengue is at least partly immune-mediated. Antibody-dependent enhancement, whereby cross-reactive antibodies from a previous infection fail to neutralise the current serotype, but instead enhance viral uptake into susceptible cells, is thought to result in a higher blood and/or tissue viral burden and a more intense immune response with increased release of vasoactive mediators $[48,49]$. Higher viraemias, considered to reflect a greater dengue-infected cell mass, have been linked to severe disease $[49,50]$, with early peak viral loads appearing to correlate with subsequent disease severity. However, serotype differences are apparent, with patients infected with DENV1 sometimes displaying extremely high plasma viraemia levels with relatively mild clinical disease $[51,52]$. The duration of viraemia has not shown a clear association with disease severity. In fact, rapid viral clearance, represented by the steepness of the decline in viraemia, has been demonstrated more commonly in DHF cases and in secondary infections, possibly as a result of a primed adaptive immune response [50]. Soluble nonstructural protein-1 (NS1) levels generally correlate with viraemia levels, and are usually higher in patients with severe than in those with uncomplicated dengue. Higher levels of NS1 within 72 hours of fever onset predicted patients who developed DHF at defervescence in one study [53], and it has been suggested that NS1 may play a pathogenic role in the capillary leakage process, through activation of complement and generation of anaphylatoxins and the terminal complement complex SC5b-9 [54]. Plasma levels of NS1 and SC5b-9 have been shown to correlate with disease severity, and were present in the pleural fluid of patients with DSS, along with the anaphylatoxin C5a. Cross-reactive NS1 antibodies have been shown invitro to target membrane-bound NS1, resulting in complementmediated cytolysis and endothelial cell disruption [55,56]. However, the kinetics of NS1 antigenaemiaare known to be influenced by several factors, including the infecting serotype, with lower levels seen in DENV2 than in DENV1 infections after adjusting for viral load, and the host immunity, with faster clearance times seen in secondary than in primary infections. Thus, the magnitude of NS1 antigenaemia alone is not sufficient to explain outcome, and this would probably affect the overall utility of NS1 as a potential biomarker $[52,57]$.

Numerous studies have investigated associations between altered levels of circulating cytokines/chemokines and complement activation markers with dengue severity. The findings from a selection of representative studies are presented in Table 1 [58-68]. However, interpretation of the data is difficult as most of the studies are small, and confounded by serotype variations and differences in plasma viraemia levels, the age and immune status of the patients, and the timing of sampling during the evolution of the infection. In addition, it is possible that the parameters of interest are influenced by the degree of capillary leakage, making comparisons of plasma measurements between severity groups unreliable.

\section{Markers of endothelial activation or microvascular disruption}

As the vascular system is targeted in dengue infections, there may be a stronger biological rationale for investigating markers specifically implicated in vascular pathology. Soluble intercellular adhesion molecule-1 (sICAM-1) and soluble vascular cell adhesion molecule-1 (sVCAM-1) have been shown to be increased in patients with dengue compared with controls, and to correlate with disease severity [70]. Similarly, sVCAM-1, sICAM-1 and E-selectin were raised in patients with dengue compared with patients with other febrile illness 1 day prior to defervescence [71]. Soluble thrombomodulin, a non-specific marker of endothelial activation, was also found to be increased 2 to 3 days before defervescence in that study, and to correlate well with disease severity [71]. Angiopoietin-2 is a protein secreted from endothelial cells in response to inflammatory stimuli, which antagonises angiopoietin-1, a protein required to maintain effective microvascular barrier function. In one study, reduced levels of angiopoietin-1 and increased levels of angiopoietin-2 were demonstrated in dengue cases at hospital admission compared with levels obtained at discharge and also compared with levels seen in healthy controls, and these changes correlated with plasma leakage and disease severity [72].

In addition to markers of endothelial activation, a few studies have examined factors more directly indicative of disruption of the endothelial barrier. Although morphological examination has revealed only minor non-specific changes in microvascular structure, increased circulating endothelial cells (CECs) have been demonstrated in patients with dengue, with the levels correlating with severity $[70,71]$. However, even if confirmed to be useful for risk prediction, the techniques required to measure CECs are complex and assay standardisation is difficult, making it unlikely that CEC measurement could be widely deployed in endemic areas. Damage to the endothelial surface glycocalyx layer, a negatively charged gel-like structure that lines the luminal surface of the microvasculature and constitutes the primary permeability barrier, has also been implicated in the pathogenesis of severe dengue. Both the DENV envelope protein and NS1 are known to bind to heparan sulfate, a major constituent of the glyocalyx layer, potentially resulting in shedding of this layer, with consequent alterations in microvascular permeability $[73,74]$. Preliminary evidence suggests that circulating heparan sulphate levels are raised during the early febrile phase of dengue [75], although further studies are required 
Table 1 Immunological parameters as potential biomarkers

\begin{tabular}{|c|c|c|}
\hline Immune marker & Disease phase & Comment \\
\hline \multicolumn{3}{|l|}{ Elevated levels } \\
\hline$|\mathrm{L}-4,| \mathrm{L}-6, \mid \mathrm{L}-8, \mathrm{IL}-10$ & $\begin{array}{l}\text { Elevated during the febrile phase, } \\
\text { peaking around defervescence }\end{array}$ & $\begin{array}{l}\text { Elevated levels in patients with DSS compared with those with DF, } \\
\text { which correlated with markers of disease severity }[58] \text {. IL-10 correlated } \\
\text { with degree of thrombocytopenia }[49,65]\end{array}$ \\
\hline TNFa, sTNFR-75, sTNFR-80 & Elevated in the febrile phase & $\begin{array}{l}\text { Raised levels in severe dengue versus mild disease. Positive correlation } \\
\text { with disease severity. sTNFRspredicted children who subsequently } \\
\text { went on to develop shock }[64,67]\end{array}$ \\
\hline $\mathrm{IFN}-\gamma$ & $\begin{array}{l}\text { Raised in early febrile phase, peaking } \\
\text { prior to defervescence day }\end{array}$ & $\begin{array}{l}\text { DHF was associated with earlier peak IFN- } \gamma \text { levels [49]. Associated with } \\
\text { development of severe disease [59] }\end{array}$ \\
\hline MIP-1b, G-CSF, IP-10, MCP-1 & $\begin{array}{l}\text { Elevated in early febrile phase } \\
\text { through to defervescence }\end{array}$ & $\begin{array}{l}\text { Compared with healthy control, MIP-1b and G-CSF were elevated in } \\
\text { patients with uncomplicated dengue; MCP-1 in dengue with warning } \\
\text { signs; and IP-10 in both groups [62] }\end{array}$ \\
\hline C3a, C4a, C5a,Factor D & Elevated in acute phase & Elevated in DHF compared with DF [68] \\
\hline $\begin{array}{l}\text { SC5b-9 terminal complement } \\
\text { complex }\end{array}$ & $\begin{array}{l}\text { Elevated in acute disease, peaking } \\
\text { day after defervescence }\end{array}$ & $\begin{array}{l}\text { Higher levels were demonstrated in DF/DHF compared with OFI, and } \\
\text { correlated with dengue severity [54] }\end{array}$ \\
\hline \multicolumn{3}{|l|}{ Reduced levels } \\
\hline RANTES/CCL5 & $\begin{array}{l}\text { Reduced levels during the acute } \\
\text { phase }\end{array}$ & $\begin{array}{l}\text { Reduced during acute phase in patients with dengue compared with } \\
\text { healthy controls, and correlated with thrombocytopenia [66] }\end{array}$ \\
\hline IL1-b, IL-2, EGF & Reduced levels during febrile phase & $\begin{array}{l}\text { No difference was demonstrated between the severity grades for IL-1b } \\
\text { but there was significantly lower levels of IL-2 and EGF in DSS compared } \\
\text { with DF [58] }\end{array}$ \\
\hline \multirow[t]{2}{*}{ VEGF, VEGFR2 } & \multirow{2}{*}{$\begin{array}{l}\text { Altered levels of VEGF and VEGFR2 } \\
\text { around day of defervescence }\end{array}$} & There are mixed reports of VEGF levels \\
\hline & & $\begin{array}{l}\text { One study demonstrated reduced VEGF levels in DSS compared with } \\
\text { DF from } 2 \text { days before to } 2 \text { days after defervescence [58]. Other studies } \\
\text { have shown elevated VEGF levels in DHF compared with DF[69], and } \\
\text { a further study demonstrated elevated levels of free VEGF in DHF at } \\
\text { the time of plasma leakage, and reduced levels of VEGFR2 [63] }\end{array}$ \\
\hline $\mathrm{C} 3$, factor $\mathrm{H}$ & Reduced levels during acute dengue & $\begin{array}{l}\text { Reduced levels were found in patients with DHF compared with } \\
\text { those with DF and healthy controls [68] }\end{array}$ \\
\hline
\end{tabular}

C, complement; DF, dengue fever; DHF, dengue haemorrhagic fever; DSS, dengue shock syndrome;EGF, epidermal growth factor; G-CSF, granulocyte-colony stimulating factor; IFN, interferon; IL, interleukin; IP, interferon- $\gamma$-induced protein; MCP, monocyte chemoattractant protein; MIP, macrophage inflammatory protein; OFI, other febrile illness; RANTES/CCL5, regulated on activation, normal T cell expressed and secreted/chemokine (C-C motif) ligand 5; TNF, tumour necrosis factor; sTNFR, soluble tumour necrosis factor receptor; VEGF, vascular endothelial growth factor; VEGFR, vascular endothelial growth factor receptor.

to determine whether these early increases in heparan sulfate levels predict which patients are likely to develop severe disease.

Along similar lines, microparticles are submicron vesicles that are shed from the surface of cell membranes in response to activation, injury and apoptosis. It is becoming increasingly apparent that far from being simple markers of cell activation, microparticles play a critical role in the pathophysiology of various disease states. Endothelial microparticles are emerging as potential biomarkers for cardiovascular diseases, diabetes and sepsis, conditions in which vascular inflammation and injury are key to patient outcomes [76-78]. Currently, the role of endothelial microparticles in the pathogenesis of the microvascular dysfunction in dengue is not known. However in one study, platelet derived microparticles (PMPs) rich in IL-1b correlated with signs of vascular permeability in patients with dengue, and PMPs were found to induce vascular permeability invitro in an IL1-dependent manner [79].

\section{Novel methods of assessing vascular status clinically}

As outlined earlier, the defining feature of severe dengue is disruption of vascular barrier function, resulting in plasma leakage, intravascular volume depletion, and eventually cardiovascular collapse and death if appropriate fluid therapy is not instituted promptly. Current techniques to identify and monitor leakage rely on surrogate markers of intravascular volume depletion, including serial haematocrit measurements, and close observation of cardiovascular indices, particularly the pulse pressure and heart rate [10]. However, these parameters are relatively insensitive, and show little change until the critical phase of the infection (Figure 1), whereas evidence from serial ultrasound studies indicates that plasma leakage actually starts during the febrile phase [44]. It is possible that many patients experience some degree of plasma leakage, and that only a minority become haemodynamically unstable when a significant volume of fluid has extravasated, overwhelming that individual's intrinsic compensatory homeostatic mechanisms. Several new techniques designed to 
evaluate endothelial dysfunction, monitor the microcirculation, and assess intravascular volume status have been developed in recent years, and have the potential to be useful tools for predicting outcome in dengue.

\section{Evaluating endothelial dysfunction}

Greater understanding of normal microvascular physiology together with increasing recognition of the importance of endothelial dysfunction in systemic disease has led to the development of endothelial function testing in a variety of medical disciplines. Available techniques include venous plethysmography, assessment of flow-mediated dilatation of the brachial artery and peripheral artery tonometry (PAT). The latter two techniques evaluate endothelial function through monitoring the reactive hyperaemia $(\mathrm{RH})$ response following occlusion of a proximal artery.

In PAT, changes in amplitude of the digital pulse volume are postulated to reflect nitric oxide bioavailability. The increase in blood flow following an occlusion test is thought to stimulate production and release of endothelial-derived nitric oxide, causing vasodilation. The test is easy to apply, requires less staff training and has better inter-user variability than techniques to assess brachial artery dilatation, and has shown good reproducibility $[80,81]$.

Longitudinal studies involving serial $\mathrm{RH}$ assessments have demonstrated that altered endothelial responses can be identified several years prior to the occurrence of adverse cardiovascular events [82,83]. More recently, endotheliumdependent microvascular reactivity was shown to be impaired in acute sepsis in proportion to overall disease severity, and the degree of impairment at baseline predicted subsequent deterioration in organ function [84]. Studies in Plasmodium falciparum malaria have demonstrated endothelial dysfunction and decreased nitric oxide bioavailability with more marked changes in severe compared with mild malaria, and this work has led onto therapeutic intervention trials with L-arginine $[85,86]$. To date, results of clinical endothelial function tests have not been reported in dengue, but there are ongoing studies in Vietnam and Singapore. Preliminary results indicate that dysfunction occurs early, during the febrile phase, raising the possibility that this technique might be useful in predicting outcome. However, drawbacks include the need for a degree of patient cooperation, meaning that it is difficult to use the technique in younger children and unstable patients, and, at least at present, the cost of the disposable probes, which is likely to limit widespread application in resource-poor settings.

\section{Monitoring flow in the microcirculation}

Microcirculatory dysfunction causing tissue hypoperfusion is considered to play a major role in the pathophysiology of multiorgan failure in severe bacterial infections [87]. Early-onset multiorgan failure is thought to be mediated by inadequate tissue perfusion, whereas organ failure occurring later in the course of severe sepsis is likely to be related to mitochondrial failure and cell death [88]. In line with this hypothesis, haemodynamic optimization has been found to be beneficial in the early but not late stages of septic shock [89].

In the past two decades, bedside real-time imaging of the microcirculation has become possible with videomicroscopy using orthogonal polarisation spectral imaging (OPS) and side-stream darkfield imaging (SDF) [90]. It has been postulated that during the earliest phase of incipient shock, impaired microcirculatory flow and tissue hypoperfusion can be detected prior to the onset of overt cardiovascular collapse [91]. A decrease in the number of perfused capillaries, together with reduced flow rates and heterogeneity of the microcirculation, is associated with increased severity of both sepsis and malaria, and these changes are strong predictors of outcome $[91,92]$. Microcirculatory changes occur early in the course of the disease and are independent of arterial blood pressure, and their persistence is associated with mortality $[91,93]$. At present, alterations to microcirculatory flow patterns in dengue are largely unknown. In one case study from Brazil involving two patients with DSS, very abnormal microcirculatory patterns were identified, which improved following resolution of shock [94]. Our group in Vietnam is currently investigating the microcirculation using SDF technology in a large study of patients with suspected dengue, carrying out serial examinations from the early febrile phase throughout the evolution of the illness to see if the technique has prognostic value (Figure 2).

\section{Monitoring intravascular volume status}

The ability to detect and measure changes in intravascular volume early in the evolution of dengue, particularly during the compensated phase of shock, would be of real benefit for patient management. The compensatory reserve index (CRI) is a new computational algorithm that uses feature analysis of the arterial pulse waveform to track real-time changes in central blood volume [95]. Arterial waveform data are processed by the algorithm to calculate a CRI value between 0 and 1, where 1 represents normovolaemia and 0 represents the point of decompensation [96]. The CRI has been shown to correlate with estimated volume changes in a human disease model that simulates hypovolaemia due to haemorrhage, and to detect changes that occur during the compensatory phase of shock, preceding changes in conventional haemodynamic parameters. In addition, the index has been shown to distinguish between individuals with high and low tolerance to intravascular volume loss, and may therefore be helpful in identifying patients who are more vulnerable to shock. One advantage of 


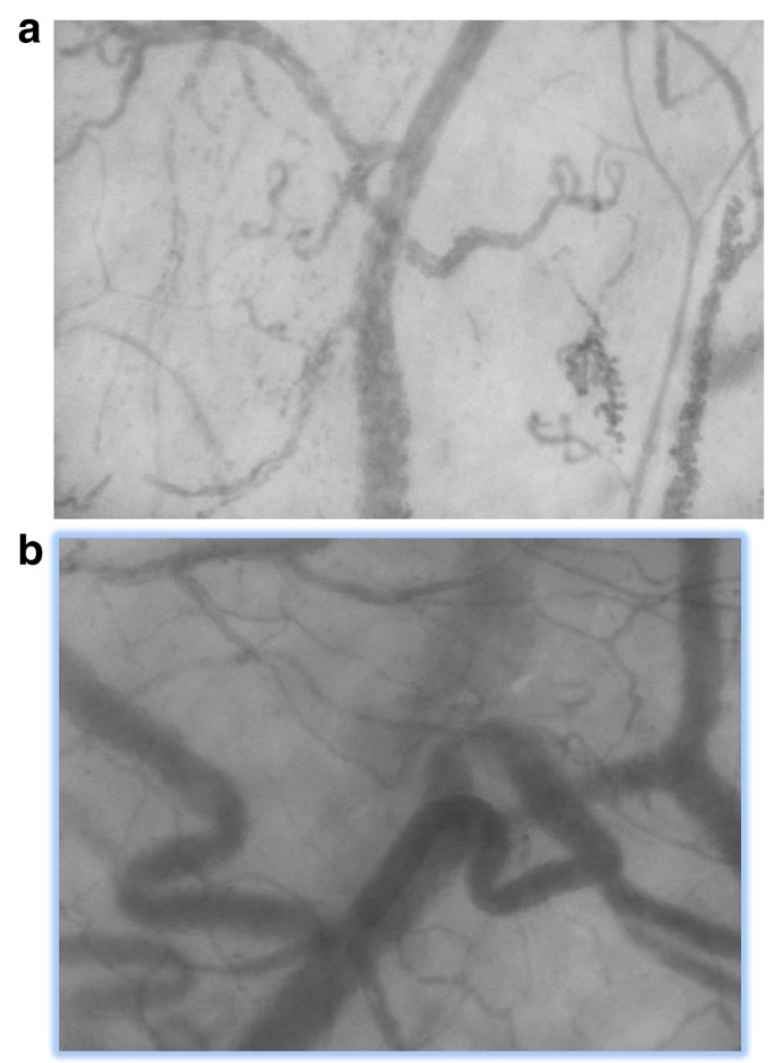

Figure 2 Side-stream darkfield imaging (SDF) in dengue.

Example of still SDF images from (a) a patient with dengue in the late febrile phase, showing reduced total vessel density and perfused vessel density, plus extravasated red cells in the left upper and lower quadrants; (b) the same patient in the recovery phase with normal vessel density, flow rate and perfusion indices.

this technique is that the CRI can be obtained from any standard monitor that generates a pulse waveform, including a finger pulse oximeter, and it is therefore completely non-invasive and relatively inexpensive. Studies to assess the utility of the CRI in predicting likely progression to shock, and to track fluid resuscitation status in patients with established shock, are ongoing in Southeast Asia.

Another non-invasive bedside technique with potential for monitoring intravascular volume is portable echocardiography [97]. Echocardiograms have the additional benefit of providing a functional cardiac assessment as well as an estimate of intravascular volume status, and are increasingly being used for haemodynamic assessment in patients with septic shock [98]. Cardiac involvement is now recognized as a feature of dengue [99], particularly in severe cases where myocardial impairment probably acts in concert with hypovolaemia to compound haemodynamic instability [100]. In such cases, assessing collapsibility of the inferior vena cava may be useful in predicting which patients are likely to be fluid-responsive. Although this method has been used mainly for ventilated patients [101], evidence is emerging that it may also be useful in spontaneously breathing patients [102]. Cardiac dysfunction probably also plays a role in less severe dengue disease. In one paediatric study, reduced cardiac output during the febrile phase was identified as being related both to reduced preload and to left ventricular impairment, with no apparent change in blood pressure [103]. As portable devices become increasingly accessible worldwide, inclusion of an echocardiographic assessment to assist with dengue risk prediction is likely to become a feasible option in many mid-level healthcare facilities.

\section{Conclusion}

Predicting outcome in dengue remains challenging, and the search for more robust methods continues. Although warning signs are considered a key component for early recognition of potentially severe disease, the current evidence for any particular clinical or laboratory marker is weak. A major global study currently in progress, aiming to recruit 10,000 to 12,000 suspected dengue cases during the early febrile phase, should provide useful information for risk prediction(ClinicalTrials.govID:NCT01550016). However, given the rather broad range of signs and symptoms seen in dengue, inclusion of one or more specific biomarkers is likely to be needed in order to develop a robust algorithm. A number of viral, immunological and endothelial biomarkers have been proposed from small studies, and there is hope that, if these arevalidated in a large patient cohort, algorithms incorporating such biomarkers might prove sufficiently sensitive and specific to be clinically useful, particularly in endemic areas where the case burden is high. However, as the vascular system is the essential target in severe dengue, alternative approaches that focus primarily on the clinical vascular function tests described above could also prove to be helpful. Although these are relatively expensive and limited to centres with specialist expertise at present, if these are shown to be reliable, their non-invasive nature makes them an attractive option, especially for repeated assessments on children, and costs are likely to come down if the techniques are widely deployed. Finally, ongoing research efforts directed towards identifying robust early predictors for severe disease are crucial to ensure that if effective antiviral or disease-modifying drugs do become available in the future, these agents can be used to maximal advantage for the patients most at risk.

\section{Competing interests}

The authors declare that that they have no competing interests.

\section{Authors' contributions}

Both authors designed the outline of the article. SY wrote the initial draft, and BW revised and expanded the manuscript. Both authors have seen and approved the final manuscript. 


\section{Authors' information}

SY is a Clinical Research Fellow studying dengue as part of the Imperial College Wellcome Trust Clinical PhD programme, and is based at the Oxford University Clinical Research Unit (OUCRU) in Vietnam. BW is the head of the Dengue Research Group at OUCRU, and Professor of Tropical Medicine at Oxford University, UK.

\section{Author details}

'Oxford University Clinical Research Unit, Wellcome Trust Major Overseas Programme, Hospital for Tropical Diseases, 764 Vo Van Kiet Street, Ho Chi Minh City, Vietnam. ²Department of Medicine, Imperial College, Hammersmith Campus, London, UK. ${ }^{3}$ Nuffield Department of Clinical Medicine, Centre for Tropical Medicine, Oxford, UK.

Received: 18 June 2014 Accepted: 8 August 2014 Published: 4 September 2014

\section{References}

1. Bhatt $S$, Gething PW, Brady OJ, Messina JP, Farlow AW, Moyes CL, Drake JM, Brownstein JS, Hoen AG, Sankoh O, Myers MF, George DB, Jaenisch T, Wint GR, Simmons CP, Scott TW, Farrar J, Hay SI: The global distribution and burden of dengue. Nature 2013, 496:504-507.

2. Simmons CP, Farrar JJ, Nguyen W, Wills B: Dengue. N Engl J Med 2012, 366:1423-1432.

3. Yacoub S, Mongkolsapaya J, Screaton G: The pathogenesis of dengue. CurrOpin Infect Dis 2013, 26:284-9.

4. Tassniyom S, Vasanawathana S, Chirawatkul A, Rojanasuphot S: Failure of high-dose methylprednisolone in established dengue shock syndrome: a placebo-controlled, double-blind study. Pediatrics 1993, 92:111-115.

5. Tricou V, Minh NN, Van TP, Lee SJ, Farrar J, Wills B, Tran HT, Simmons CP: A randomized controlled trial of chloroquine for the treatment of dengue in Vietnamese adults. PLoSNegl Trop Dis 2010, 4:e785.

6. Nguyen NM, Tran CN, Phung LK, Duong KT, Huynh HL, Farrar J, Nguyen QT, Tran HT, Nguyen CV, Merson L, Hoang LT, Hibberd ML, Aw PP, Wilm A, Nagarajan N, Nguyen DT, Pham MP, Nguyen TT, Javanbakht H, Klumpp K, Hammond J, Petric R, Wolbers M, Nguyen CT, Simmons CP: A randomized, double-blind placebo controlled trial of balapiravir, a polymerase inhibitor, in adult dengue patients. J Infect Dis 2013, 207:1442-50.

7. Low JG, Sung C, Wijaya L, Wei Y, Rathore AP, Watanabe S, Tan BH, Toh L, Chua LT, Hou Y, Chow A, Howe S, Chan WK, Tan KH, Chung JS, Cherng BP, Lye DC, Tambayah PA, Ng LC, Connolly J, Hibberd ML, Leo YS, Cheung YB, Ooi EE, Vasudevan SG: Efficacy and safety of celgosivir in patients with dengue fever (CELADEN): a phase $1 \mathrm{~b}$, randomised, double-blind, placebo-controlled, proof-of-concept trial. Lancet Infect Dis 2014, 14:706-15.

8. Wills BA, Nguyen MD, Ha TL, Dong TH, Tran TN, Le TT, Tran VD, Nguyen TH, Nguyen VC, Stepniewska K, White NJ, Farrar JJ: Comparison of three fluid solutions for resuscitation in dengue shock syndrome. N Engl J Med 2005 353:877-889.

9. Lam PK, Tam DT, Diet TV, Tam CT, Tien NT, Kieu NT, Simmons C, Farrar J, Nga NT, Qui PT, Dung NM, Wolbers M, Wills B: Clinical characteristics of dengue shock syndrome in Vietnamese children: a 10-year prospective study in a single hospital. Clin Infect Dis 2013, 57:1577-1586.

10. Special Programme for Research and Training in Tropical Diseases, World Health Organization: Dengue: Guidelines for Diagnosis, Treatment, Prevention, and Control, New edn. Geneva: TDR/World Health Organization; 2009

11. Alexander N, Balmaseda A, Coelho IC, Dimaano E, Hien TT, Hung NT, Janisch T, Kroeger A, Lum LC, Martinez E, Siqueira JB, Thuy TT, Villalobos I, Villegas E, Wills B: Multicentre prospective study on dengue classification in four South-east Asian and three Latin American countries. Trop Med Int Health 2011, 16:936-948.

12. Dengue guidelines for diagnosis, treatment, prevention and control: new edition. http://www.who.int/rpc/guidelines/9789241547871/en/.

13. Guzman MG, Alvarez M, Halstead SB: Secondary infection as a risk factor for dengue hemorrhagic fever/dengue shock syndrome: an historical perspective and role of antibody-dependent enhancement of infection. Arch Virol 2013, 158:1445-1459.

14. Hammond SN, Balmaseda A, Perez L, Tellez Y, Saborio SI, Mercado JC, Videa E, Rodriguez Y, Perez MA, Cuadra R, Solano S, Rocha J, Idiaquez W, Gonzalez A, Harris E: Differences in dengue severity in infants, children, and adults in a 3-year hospital-based study in Nicaragua. Am J Trop Med Hyg 2005, 73:1063-1070.

15. Lee MS, Hwang KP, Chen TC, Lu PL, Chen TP: Clinical characteristics of dengue and dengue hemorrhagic fever in a medical center of southern Taiwan during the 2002 epidemic. J Microbiol Immunol Infect 2006, 39:121-129.

16. Machado CR, Machado ES, Rohloff RD, Azevedo M, Campos DP, de Oliveira $\mathrm{RB}$, Brasil P: Is pregnancy associated with severe dengue? A review of data from the Rio de Janeiro surveillance information system. PLoS Negl Trop Dis 2013, 7:e2217

17. Kalayanarooj S, Nimmannitya S: Is dengue severity related to nutritional status? Southeast Asian J Trop Med Public Health 2005, 36:378-384

18. Pang J, Salim A, Lee VJ, Hibberd ML, Chia KS, Leo YS, Lye DC: Diabetes with hypertension as risk factors for adult dengue hemorrhagic fever in a predominantly dengue serotype 2 epidemic: a case control study. PLoS Negl Trop Dis 2012, 6:e1641.

19. Anders KL, Nguyet NM, Chau NV, Hung NT, Thuy TT, le Lien B, Farrar J, Wills B, Hien TT, Simmons CP: Epidemiological factors associated with dengue shock syndrome and mortality in hospitalized dengue patients in $\mathrm{Ho} C \mathrm{Chi}$ Minh City, Vietnam. Am J Trop Med Hyg 2011, 84:127-134.

20. Huy NT, Van Giang T, Thuy DH, Kikuchi M, Hien TT, Zamora J, Hirayama K: Factors associated with dengue shock syndrome: a systematic review and meta-analysis. PLoS Negl Trop Dis 2013, 7:e2412.

21. Shekhar KC, Huat OL: Epidemiology of dengue/dengue hemorrhagic fever in Malaysia-a retrospective epidemiological study. 1973-1987. Part II: Dengue fever (DF). Asia Pac J Public Health 1992, 6:126-133.

22. Phuong CX, Nhan NT, Kneen R, Thuy PT, van Thien C, Nga NT, Thuy $T$, Solomon T, Stepniewska K, Wills B: Clinical diagnosis and assessment of severity of confirmed dengue infections in Vietnamese children: is the World Health Organization classification system helpful? Am J Trop Med Hyg 2004, 70:172-179.

23. Cao XT, Ngo TN, Wills B, Kneen R, Nguyen TT, Ta TT, Tran TT, Doan TK, Solomon T, Simpson JA, White NJ, Farrar JJ: Evaluation of the World Health Organization standard tourniquet test and a modified tourniquet test in the diagnosis of dengue infection in Viet Nam. Trop Med Int Health 2002, 7:125-132.

24. Wali JP, Biswas A, Aggarwal P, Wig N, Handa R: Validity of tourniquet test in dengue haemorrhagic fever. J Assoc Physicians India 1999, 47:203-204.

25. Lee VJ, Lye DC, Sun Y, Leo YS: Decision tree algorithm in deciding hospitalization for adult patients with dengue haemorrhagic fever in Singapore. Trop Med Int Health 2009, 14:1154-1159.

26. Thein TL, Leo YS, Lee VJ, Sun Y, Lye DC: Validation of probability equation and decision tree in predicting subsequent dengue hemorrhagic fever in adult dengue inpatients in Singapore. Am J Trop Med Hyg 2011, 85:942-945.

27. Potts JA, Rothman AL: Clinical and laboratory features that distinguish dengue from other febrile illnesses in endemic populations. Trop Med Int Health 2008, 13:1328-1340.

28. Trung DT, le Thao TT, Dung NM, Ngoc TV, Hien TT, Chau NV, Wolbers M, Tam DT, Farrar J, Simmons C, Wills B: Clinical features of dengue in a large Vietnamese cohort: intrinsically lower platelet counts and greater risk for bleeding in adults than children. PLoS Negl Trop Dis 2012, 6:e1679.

29. Brasier AR, Ju H, Garcia J, Spratt HM, Victor SS, Forshey BM, Halsey ES, Comach G, Sierra G, Blair PJ, Rocha C, Morrison AC, Scott TW, Bazan I, Kochel TJ: A three-component biomarker panel for prediction of dengue hemorrhagic fever. Am J Trop Med Hyg 2012, 86:341-348.

30. Krishnamurti C, Kalayanarooj S, Cutting MA, Peat RA, Rothwell SW, Reid TJ, Green S, Nisalak A, Endy TP, Vaughn DW, Nimmannitya S, Innis BL: Mechanisms of hemorrhage in dengue without circulatory collapse. Am J Trop Med Hyg 2001, 65:840-847.

31. Wills B, Tran VN, Nguyen TH, Truong TT, Tran TN, Nguyen MD, Tran VD, Nguyen W, Dinh TT, Farrar J: Hemostatic changes in Vietnamese children with mild dengue correlate with the severity of vascular leakage rather than bleeding. Am J Trop Med Hyg 2009, 81:638-644.

32. WHO: Dengue: Guidelines for Treatment, Prevention and Control. Geneva: World Health Organization; 2009.

33. Potts JA, Gibbons RV, Rothman AL, Srikiatkhachorn A, Thomas SJ, Supradish PO, Lemon SC, Libraty DH, Green S, Kalayanarooj S: Prediction of dengue disease severity among pediatric Thai patients using early clinical laboratory indicators. PLoS Negl Trop Dis 2010, 4:e769.

34. Wichmann O, Gascon J, Schunk M, Puente S, Siikamaki H, Gjorup I, LopezVelez R, Clerinx J, Peyerl-Hoffmann G, Sundoy A, Genton B, Kern P, Calleri G, 
de Gorgolas M, Muhlberger N, Jelinek T: Severe dengue virus infection in travelers: risk factors and laboratory indicators. J Infect Dis 2007, 195:1089-1096.

35. Trung DT, le Thao T, Hien TT, Hung NT, Vinh NN, Hien PT, Chinh NT, Simmons C, Wills B: Liver involvement associated with dengue infection in adults in Vietnam. Am J Trop Med Hyg 2010, 83:774-780.

36. Lee LK, Gan VC, Lee VJ, Tan AS, Leo YS, Lye DC: Clinical relevance and discriminatory value of elevated liver aminotransferase levels for dengue severity. PLoS Negl Trop Dis 2012, 6:e1676.

37. Wills BA, Oragui EE, Dung NM, Loan HT, Chau NV, Farrar JJ, Levin M: Size and charge characteristics of the protein leak in dengue shock syndrome. J Infect Dis 2004, 190:810-818.

38. Vasanwala FF, Thein TL, Leo YS, Gan VC, Hao Y, Lee LK, Lye DC: Predictive value of proteinuria in adult dengue severity. PLOS Negl Trop Dis 2014 8:e2712.

39. Hanh Tien NT, Lam PK, Duyen HT, Ngoc TV, Ha PT, Kieu NT, Simmons C, Wolbers M, Wills B: Assessment of microalbuminuria for early diagnosis and risk prediction in dengue infections. PLOS One 2013, 8:e54538.

40. Bharath Kumar Reddy KR, Laksmana RR, Veerappa BG: Shivananda: Ultrasonography as a tool in predicting the severity of dengue fever in children-a useful aid in a developing country. Pediatr Radiol 2013, 43:971-977.

41. Setiawan MW, Samsi TK, Wulur H, Sugianto D, Pool TN: Dengue haemorrhagic fever: ultrasound as an aid to predict the severity of the disease. Pediatr Radiol 1998, 28:1-4

42. Colbert JA, Gordon A, Roxelin R, Silva S, Silva J, Rocha C, Harris E: Ultrasound measurement of gallbladder wall thickening as a diagnostic test and prognostic indicator for severe dengue in pediatric patients. Pediatr Infect Dis J 2007, 26:850-852.

43. Srikiatkhachorn A, Krautrachue A, Ratanaprakarn W, Wongtapradit L, Nithipanya N, Kalayanarooj S, Nisalak A, Thomas SJ, Gibbons RV, Mammen MP Jr, Libraty DH, Ennis FA, Rothman AL, Green S: Natural history of plasma leakage in dengue hemorrhagic fever: a serial ultrasonographic study. Pediatr Infect Dis J 2007 26:283-290.

44. Michels M, Sumardi U, de Mast Q, Jusuf H, Puspita M, Dewi IM, Sinarta S, Alisjahbana B, van der Ven AJ: The predictive diagnostic value of serial daily bedside ultrasonography for severe dengue in Indonesian adults. PLoS Negl Trop Dis 2013, 7:e2277.

45. Runner GJ, Corwin MT, Siewert B, Eisenberg RL: Gallbladder wall thickening. AJR Am J Roentgenol 2014, 202:W1-W12.

46. Sangkawibha N, Rojanasuphot $S$, Ahandrik S, Viriyapongse S, Jatanasen S, Salitul V, Phanthumachinda B, Halstead SB: Risk factors in dengue shock syndrome: a prospective epidemiologic study in Rayong, Thailand. I. The 1980 outbreak. Am J Epidemiol 1984, 120:653-669.

47. Guzman MG, Kouri G, Valdes L, Bravo J, Alvarez M, Vazques S, Delgado I, Halstead SB: Epidemiologic studies on dengue in Santiago de Cuba, 1997. Am J Epidemiol 2000, 152:793-799.

48. Halstead SB, O'Rourke EJ: Antibody-enhanced dengue virus infection in primate leukocytes. Nature 1977, 265:739-741

49. Libraty DH, Endy TP, Houng HS, Green S, Kalayanarooj S, Suntayakorn S, Chansiriwongs W, Vaughn DW, Nisalak A, Ennis FA, Rothman AL: Differing influences of virus burden and immune activation on disease severity in secondary dengue-3 virus infections. J Infect Dis 2002, 185:1213-1221.

50. Vaughn DW, Green S, Kalayanarooj S, Innis BL, Nimmannitya S, Suntayakorn S, Endy TP, Raengsakulrach B, Rothman AL, Ennis FA, Nisalak A: Dengue viremia titer, antibody response pattern, and virus serotype correlate with disease severity. J Infect Dis 2000, 181:2-9.

51. Gubler DJ, Suharyono W, Tan R, Abidin M, Sie A: Viraemia in patients with naturally acquired dengue infection. Bull World Health Organ 1981, 59:623-630.

52. Duyen HT, Ngoc TV, Do Ha T, Hang VT, Kieu NT, Young PR, Farrar JJ, Simmons CP, Wolbers M, Wills BA: Kinetics of plasma viremia and soluble nonstructural protein 1 concentrations in dengue: differential effects according to serotype and immune status. J Infect Dis 2011, 203:1292-1300.

53. Libraty DH, Young PR, Pickering D, Endy TP, Kalayanarooj S, Green S, Vaughn DW, Nisalak A, Ennis FA, Rothman AL: High circulating levels of the dengue virus nonstructural protein NS1 early in dengue illness correlate with the development of dengue hemorrhagic fever. $J$ Infect Dis 2002, 186:1165-1168.

54. Avirutnan P, Punyadee N, Noisakran S, Komoltri C, Thiemmeca S, Auethavornanan K, Jairungsri A, Kanlaya R, Tangthawornchaikul N,
Puttikhunt C, Pattanakitsakul SN, Yenchitsomanus PT, Mongkolsapaya J, Kasinrerk W, Sittisombut N, Husmann M, Blettner M, Vasanawathana S, Bhakdi S, Malasit P: Vascular leakage in severe dengue virus infections: a potential role for the nonstructural viral protein NS1 and complement. $J$ Infect Dis 2006, 193:1078-1088.

55. Lin CF, Lei HY, Shiau AL, Liu HS, Yeh TM, Chen SH, Liu CC, Chiu SC, Lin YS: Endothelial cell apoptosis induced by antibodies against dengue virus nonstructural protein 1 via production of nitric oxide. J Immunol 2002, 169:657-664.

56. Lin CF, Lei HY, Shiau AL, Liu CC, Liu HS, Yeh TM, Chen SH, Lin YS: Antibodies from dengue patient sera cross-react with endothelial cells and induce damage. J Med Virol 2003, 69:82-90.

57. Duong V, Ly S, Lorn Try P, Tuiskunen A, Ong S, Chroeung N, Lundkvist A, Leparc-Goffart I, Deubel V, Vong S, Buchy P: Clinical and virological factors influencing the performance of a NS1 antigen-capture assay and potential use as a marker of dengue disease severity. PLoS Negl Trop Dis 2011, 5:e1244.

58. Butthep P, Chunhakan S, Yoksan S, Tangnararatchakit K, Chuansumrit A: Alteration of cytokines and chemokines during febrile episodes associated with endothelial cell damage and plasma leakage in dengue hemorrhagic fever. Pediatr Infect Dis J 2012, 31:e232-e238.

59. Bozza FA, Cruz OG, Zagne SM, Azeredo EL, Nogueira RM, Assis EF, Bozza PT, Kubelka CF: Multiplex cytokine profile from dengue patients: MIP-1beta and IFN-gamma as predictive factors for severity. BMC Infect Dis 2008, 8:86.

60. Chaturvedi UC, Elbishbishi EA, Agarwal R, Raghupathy R, Nagar R, Tandon R, Pacsa AS, Younis OI, Azizieh F: Sequential production of cytokines by dengue virus-infected human peripheral blood leukocyte cultures. J Med Virol 1999, 59:335-340

61. Juffrie M, Meer GM, Hack CE, Haasnoot K, Sutaryo, Veerman AJ, Thijs LG: Inflammatory mediators in dengue virus infection in children: interleukin-6 and its relation to C-reactive protein and secretory phospholipase A2. Am J Trop Med Hyg 2001, 65:70-75.

62. Rathakrishnan A, Wang SM, Hu Y, Khan AM, Ponnampalavanar S, Lum LC, Manikam R, Sekaran SD: Cytokine expression profile of dengue patients at different phases of illness. PLoS One 2012, 7:e52215.

63. Srikiatkhachorn A, Ajariyakhajorn C, Endy TP, Kalayanarooj S, Libraty DH, Green S, Ennis FA, Rothman AL: Virus-induced decline in soluble vascular endothelial growth receptor 2 is associated with plasma leakage in dengue hemorrhagic Fever. J Virol 2007, 81:1592-1600.

64. Green S, Vaughn DW, Kalayanarooj S, Nimmannitya S, Suntayakorn S, Nisalak A, Lew R, Innis BL, Kurane I, Rothman AL, Ennis FA: Early immune activation in acute dengue illness is related to development of plasma leakage and disease severity. J Infect Dis 1999, 179:755-762.

65. Green S, Vaughn DW, Kalayanarooj S, Nimmannitya S, Suntayakorn S, Nisalak A, Rothman AL, Ennis FA: Elevated plasma interleukin-10 levels in acute dengue correlate with disease severity. J Med Virol 1999, 59:329-334.

66. De-Oliveira-Pinto LM, Marinho CF, Povoa TF, de Azeredo EL, de Souza LA, Barbosa LD, Motta-Castro AR, Alves AM, Avila CA, de Souza LJ, da Cunha RV, Damasco PV, Paes MV, Kubelka CF: Regulation of inflammatory chemokine receptors on blood T cells associated to the circulating versus liver chemokines in dengue fever. PLoS One 2012, 7:e38527.

67. Bethell DB, Flobbe K, Cao XT, Day NP, Pham TP, Buurman WA, Cardosa MJ, White NJ, Kwiatkowski D: Pathophysiologic and prognostic role of cytokines in dengue hemorrhagic fever. J Infect Dis 1998, 177:778-782

68. Nascimento EJ, Silva AM, Cordeiro MT, Brito CA, Gil LH, Braga-Neto U, Marques ET: Alternative complement pathway deregulation is correlated with dengue severity. PLoS One 2009, 4:e6782.

69. Tseng CS, Lo HW, Teng HC, Lo WC, Ker CG: Elevated levels of plasma VEGF in patients with dengue hemorrhagic fever. FEMS Immunol Med Microbiol 2005, 43:99-102.

70. Cardier JE, Rivas B, Romano E, Rothman AL, Perez-Perez C, Ochoa M, Caceres AM, Cardier M, Guevara N, Giovannetti R: Evidence of vascular damage in dengue disease: demonstration of high levels of soluble cell adhesion molecules and circulating endothelial cells. Endothelium 2006, 13:335-340.

71. Butthep P, Chunhakan S, Tangnararatchakit K, Yoksan S, Pattanapanyasat K, Chuansumrit A: Elevated soluble thrombomodulin in the febrile stage related to patients at risk for dengue shock syndrome. Pediatr Infect Dis J 2006, 25:894-897.

72. Michels M, van der Ven AJ, Djamiatun K, Fijnheer R, de Groot PG, Griffioen AW, Sebastian S, Faradz SM, de Mast Q: Imbalance of angiopoietin-1 and 
angiopoetin-2 in severe dengue and relationship with thrombocytopenia, endothelial activation, and vascular stability. Am J Trop Med Hyg 2012, 87:943-946.

73. Chen Y, Maguire T, Hileman RE, Fromm JR, Esko JD, Linhardt RJ, Marks RM: Dengue virus infectivity depends on envelope protein binding to target cell heparan sulfate. Nat Med 1997, 3:866-871.

74. Avirutnan P, Zhang L, Punyadee N, Manuyakorn A, Puttikhunt C, Kasinrerk W, Malasit P, Atkinson JP, Diamond MS: Secreted NS1 of dengue virus attaches to the surface of cells via interactions with heparan sulfate and chondroitin sulfate E. PLOS Pathog 2007, 3:e183.

75. Tam DT, Ngoc TV, Tien NT, Kieu NT, Thuy TT, Thanh LT, Tam CT, Truong NT, Dung NT, Qui PT, Hien TT, Farrar JJ, Simmons CP, Wolbers M, Wills BA: Effects of short-course oral corticosteroid therapy in early dengue infection in Vietnamese patients: a randomized, placebo-controlled trial. Clin Infect Dis 2012, 55:1216-1224.

76. Viera AJ, Mooberry M, Key NS: Microparticles in cardiovascular disease pathophysiology and outcomes. J Am Soc Hypertens 2012, 6:243-252.

77. Soriano AO, Jy W, Chirinos JA, Valdivia MA, Velasquez HS, Jimenez JJ, Horstman LL, Kett DH, Schein RM, Ahn YS: Levels of endothelial and platelet microparticles and their interactions with leukocytes negatively correlate with organ dysfunction and predict mortality in severe sepsis. Crit Care Med 2005, 33:2540-2546.

78. Abebe W, Mozaffari M: Endothelial dysfunction in diabetes: potential application of circulating markers as advanced diagnostic and prognostic tools. EPMA J 2010, 1:32-45.

79. Hottz ED, Lopes JF, Freitas C, Valls-de-Souza R, Oliveira MF, Bozza MT, Da Poian AT, Weyrich AS, Zimmerman GA, Bozza FA, Bozza PT: Platelets mediate increased endothelium permeability in dengue through NLRP3-inflammasome activation. Blood 2013, 122:3405-3414.

80. Hamburg NM, Keyes MJ, Larson MG, Vasan RS, Schnabel R, Pryde MM Mitchell GF, Sheffy J, Vita JA, Benjamin EJ: Cross-sectional relations of digital vascular function to cardiovascular risk factors in the Framingham Heart Study. Circulation 2008, 117:2467-2474.

81. Dhindsa M, Sommerlad SM, DeVan AE, Barnes JN, Sugawara J, Ley O, Tanaka H: Interrelationships among noninvasive measures of postischemic macro- and microvascular reactivity. J Appl Physio/ 2008, 105:427-432

82. Rubinshtein R, Kuvin JT, Soffler M, Lennon RJ, Lavi S, Nelson RE, Pumper GM, Lerman LO, Lerman A: Assessment of endothelial function by non-invasive peripheral arterial tonometry predicts late cardiovascular adverse events. Eur Heart J 2010, 31:1142-1148.

83. Hedblad B, Ogren M, Janzon L, Isacsson SO, Lindell SE: Low pulse-wave amplitude during reactive leg hyperaemia: an independent, early marker for ischaemic heart disease and death. Results from the 21-year follow-up of the prospective cohort study 'Men born in 1914', Malmo, Sweden. J Intern Med 1994, 236:161-168.

84. Davis JS, Yeo TW, Thomas JH, McMillan M, Darcy CJ, McNeil YR, Cheng AC, Celermajer DS, Stephens DP, Anstey NM: Sepsis-associated microvascular dysfunction measured by peripheral arterial tonometry: an observational study. Crit Care 2009, 13:R155.

85. Yeo TW, Lampah DA, Gitawati R, Tjitra E, Kenangalem E, McNeil YR, Darcy CJ, Granger DL, Weinberg JB, Lopansri BK, Price RN, Duffull SB, Celermajer DS, Anstey NM: Impaired nitric oxide bioavailability and L-arginine reversible endothelial dysfunction in adults with falciparum malaria. J Exp Med 2007, 204:2693-2704.

86. Yeo TW, Lampah DA, Gitawati R, Tjitra E, Kenangalem E, McNeil YR, Darcy CJ, Granger DL, Weinberg JB, Lopansri BK, Price RN, Duffull SB, Celermajer DS, Anstey NM: Recovery of endothelial function in severe falciparum malaria: relationship with improvement in plasma L-arginine and blood lactate concentrations. J Infect Dis 2008, 198:602-608.

87. Vincent $J \mathrm{~L}$, De Backer $\mathrm{D}$ : Microvascular dysfunction as a cause of organ dysfunction in severe sepsis. Crit Care 2005, 9:S9-S12.

88. Singer M: Cellular dysfunction in sepsis. Clin Chest Med 2008, 29:655-660. viii-ix.

89. Rivers EP, Jaehne AK, Eichhorn-Wharry L, Brown S, Amponsah D: Fluid therapy in septic shock. Curr Opin Crit Care 2010, 16:297-308.

90. De Backer D, Ospina-Tascon G, Salgado D, Favory R, Creteur J, Vincent JL Monitoring the microcirculation in the critically ill patient: current methods and future approaches. Intensive Care Med 2010, 36:1813-1825.

91. Trzeciak S, Dellinger RP, Parrillo JE, Guglielmi M, Bajaj J, Abate NL, Arnold RC, Colilla S, Zanotti S, Hollenberg SM: Early microcirculatory perfusion derangements in patients with severe sepsis and septic shock: relationship to hemodynamics, oxygen transport, and survival. Ann Emerg Med 2007, 49:88-98. 98 e81-82

92. Dondorp AM, Ince C, Charunwatthana P, Hanson J, van Kuijen A, Faiz MA, Rahman MR, Hasan M, Bin Yunus E, Ghose A, Ruangveerayut R, Limmathurotsakul D, Mathura K, White NJ, Day NP: Direct in vivo assessment of microcirculatory dysfunction in severe falciparum malaria. $J$ Infect Dis 2008, 197:79-84.

93. Spanos A, Jhanji S, Vivian-Smith A, Harris T, Pearse RM: Early microvascular changes in sepsis and severe sepsis. Shock 2010, 33:387-391.

94. Caixeta DM, Fialho FM, Azevedo ZM, Collett-Solberg PF, Villela NR, Bouskela E: Evaluation of sublingual microcirculation in children with dengue shock. Clinics 2013, 68:1061-1064

95. Convertino VA, Grudic G, Mulligan J, Moulton S: Estimation of individual-specific progression to impending cardiovascular instability using arterial waveforms. J Appl Physiol (1985) 2013, 115:1196-1202.

96. Moulton SL, Mulligan J, Grudic GZ, Convertino VA: Running on empty? The compensatory reserve index. J Trauma Acute Care Surg 2013, 75:1053-1059.

97. Seppelt IM, Orde SR: Why guess when you can see? Heart function and fluid management in dengue shock. Crit Care Med 2012, 40:675-676.

98. Griffee MJ, Merkel MJ, Wei KS: The role of echocardiography in hemodynamic assessment of septic shock. Crit Care Clin 2010, 26:365-382. table of contents.

99. Yacoub S, Wertheim H, Simmons CP, Screaton G, Wills B: Cardiovascular manifestations of the emerging dengue pandemic. Nat Rev Cardio/ 2014 11:335-45.

100. Yacoub S, Griffiths A, Chau TT, Simmons CP, Wills B, Hien TT, Henein M, Farrar J: Cardiac function in Vietnamese patients with different dengue severity grades. Crit Care Med 2012, 40:477-483.

101. Barbier C, Loubieres Y, Schmit C, Hayon J, Ricome JL, Jardin F, Vieillard-Baron A: Respiratory changes in inferior vena cava diameter are helpful in predicting fluid responsiveness in ventilated septic patients. Intensive Care Med 2004, 30:1740-1746.

102. Duwat A, Zogheib E, Guinot PG, Levy F, Trojette F, Diouf M, Slama M, Dupont H: The gray zone of the qualitative assessment of respiratory changes in inferior vena cava diameter in ICU patients. Crit Care 2014, 18:R14.

103. Khongphatthanayothin A, Suesaowalak M, Muangmingsook S, Bhattarakosol $P$, Pancharoen C: Hemodynamic profiles of patients with dengue hemorrhagic fever during toxic stage: an echocardiographic study. Intensive Care Med 2003, 29:570-574.

doi:10.1186/s12916-014-0147-9

Cite this article as: Yacoub and Wills: Predicting outcome from dengue. BMC Medicine 2014 12:147.

\section{Submit your next manuscript to BioMed Central and take full advantage of:}

- Convenient online submission

- Thorough peer review

- No space constraints or color figure charges

- Immediate publication on acceptance

- Inclusion in PubMed, CAS, Scopus and Google Scholar

- Research which is freely available for redistribution
C) Biomed Central 